\title{
Characterization of bacterial DNA binding to human neutrophil surface
}

\author{
Juan I Fuxman Bass ${ }^{1,2}$, Maria L Gabelloni ${ }^{1,2}$, María E Alvarez ${ }^{1,3}$, Mónica E Vermeulen ${ }^{1,3}$, Daniela M Russo ${ }^{4}$, \\ Ángeles Zorreguieta ${ }^{4}$, Jorge R Geffner ${ }^{1,3}$ and Analía S Trevani ${ }^{1,3}$
}

Bacterial DNA activates neutrophils through a CpG- and TLR9-independent mechanism. Neutrophil activation does not require DNA internalization, suggesting that it results from the interaction of bacterial DNA with a neutrophil surface receptor. The aim of this study was to characterize the interaction of bacterial DNA with the neutrophil surface. Bacterial DNA binding showed saturation and was inhibited by unlabeled DNA but not by other polyanions like yeast tRNA and poly-A. Resembling the conditions under which bacterial DNA triggers neutrophil activation, binding was not modified in the presence or absence of calcium, magnesium or serum. Treatment of neutrophils with proteases not only dramatically reduced bacterial DNA binding but also inhibited neutrophil activation induced by bacterial DNA. Experiments performed with DNA samples of different lengths obtained after digestion of bacterial DNA with DNase showed that only DNA fragments greater than $\approx 170-180$ nucleotides competed bacterial DNA binding and retained the ability to trigger cell activation. Treatment of neutrophils with chemoattractants or conventional agonists significantly increased bacterial DNA binding. Moreover, neutrophils that underwent transmigration through human endothelial cell monolayers even in the absence of chemoattractants, exhibited higher binding levels of bacterial DNA. Together, our findings provide evidence that binding of bacterial DNA to neutrophils is a receptor-mediated process that conditions the ability of DNA to trigger cell activation. We speculate that neutrophil recognition of bacterial DNA might be modulated by the balance of agonists present at inflammatory foci. This effect might be relevant in bacterial infections with a biofilm etiology, in which extracellular DNA could function as a potent neutrophil agonist.

Laboratory Investigation (2008) 88, 926-937; doi:10.1038/labinvest.2008.59; published online 14 July 2008

KEYWORDS: bacterial DNA binding; biofilm; CpG; inflammation; neutrophils; TLR9

Neutrophils are crucial players in the first line of defense against invading microbial pathogens. They mediate the phagocytosis and destruction of these microorganisms through oxygen-dependent and -independent mechanisms. They also inform and shape immune responses and contribute to the repair of tissues as well as their breakdown.,

It is well established that unmethylated-CpG motifs in bacterial DNA trigger immune cell activation by interacting with Toll-like receptor 9 (TLR9). ${ }^{3-5}$ However, we have previously demonstrated that neutrophils are activated by bacterial DNA through a CPG- and TLR9-independent mechanism. ${ }^{6,7}$ Additional studies provided evidence for the existence of pathways unrelated to the presence of $\mathrm{CpG}$ motifs through which DNA may be able to trigger cell acti- vation by TLR9-dependent or -independent mechanisms that involve endosomal translocation. ${ }^{8-12}$ Moreover, in vivo studies conducted in transgenic mice lacking TLR9 revealed a CpG-independent mechanism that contributes to the toxic effects associated with systemic delivery of cationic lipidplasmid DNA complexes in nonviral gene therapy protocols. ${ }^{13}$ On the other hand, more recent studies defined a mechanism by which bacterial DNA can activate TLR9independent and IRF-3-dependent innate immune responses when it gains access to the cytosol. ${ }^{14}$ In contrast to the mentioned reports, our previous results indicated that neutrophil activation by bacterial DNA is mediated by a mechanism that does not require DNA internalization and which can be triggered by immobilized DNA, suggesting that

\footnotetext{
'Departamento de Inmunología, Instituto de Investigaciones Hematológicas and Instituto de Estudios Oncológicos 'Fundación Maissa', Academia Nacional de Medicina, Buenos Aires, Argentina; ${ }^{2}$ Departamento de Fisiología y Biología Molecular y Celular, Facultad de Ciencias Exactas y Naturales, Universidad de Buenos Aires, Buenos Aires, Argentina; ${ }^{3}$ Departamento de Microbiología, Facultad de Medicina, Universidad de Buenos Aires, Buenos Aires, Argentina and ${ }^{4}$ Fundación Instituto Leloir, IIB-BA CONICET, Buenos Aires, Argentina

Correspondence: Dr AS Trevani, PhD, Department of Immunology, IIHEMA-Academia Nacional de Medicina, Pacheco de Melo 3081,1425 Buenos Aires, Argentina. E-mails: analiatrevani@yahoo.com.ar and atrevani@ciudad.com.ar
} 
a surface molecule is involved in DNA recognition and neutrophil activation. ${ }^{6}$ Of note, many different works have suggested that bacterial DNA and synthetic oligodeoxynucleotides (ODNs) are taken up by cells through a sequence-independent receptor-mediated mechanism, even though the identity of the receptor involved remains undefined. ${ }^{4,15}$

Several studies have demonstrated the presence of extracellular DNA in bacterial cultures. ${ }^{16-19}$ Naturally transformable bacterial species release chromosomal DNA into culture media. ${ }^{19-23}$ Extracellular bacterial DNA has also been proposed to play a role as a nutrient during starvation. In fact, previous studies have shown that Escherichia coli strains that consume DNA are more fit than those mutants unable to metabolize DNA. ${ }^{19}$ On the other hand, several independent observations have adjudicated an important role for DNA in the formation and composition of biofilms, which are structured communities of cells enclosed in self-produced hydrated polymeric matrix adherent to an inert or living surface. $^{24,25}$ Thus, we hypothesized that extracellular DNA in bacterial microenvironments might be recognized by a neutrophil surface molecule able to trigger neutrophil activation. Accordingly, here we have characterized the interaction between bacterial DNA and neutrophils.

\section{MATERIALS AND METHODS Reagents}

RPMI 1640 medium and PBS were purchased from HyClone Laboratories Inc. (Logan, UT, USA). Formyl-methionylleucyl-phenylalanine (FMLP), polyadenylic acid (poly-A), yeast transfer RNA (tRNA), phorbol myristate acetate (PMA) and EDTA were acquired from Sigma-Aldrich (St Louis, MO, USA). Ficoll and Dextran T-500 were purchased form Pharmacia Fine Chemicals (Uppsala, Sweden); Hypaque from Winthrop Products (Buenos Aires, Argentina); proteinase K (prot K) from Qiagen (GmbH, Germany); penicillin/ streptomycin and trypsin from Life Technologies (Grand Island, NY, USA); human serum albumin (HSA) from Laboratorio de Hemoderivados (Córdoba, Argentina); agarose and weight markers were obtained from Promega (Madison, WI, USA). Interleukin-8 (IL-8) was purchased from Peprotech (Mexico). DNA from E. coli was purchased from Worthington Biochemical Corporation (Lakewood, NJ, USA). DNA was purified by extraction with phenol:chloroform:isoamyl alcohol and ethanol precipitation and was further passed through a polymyxin-agarose column (Sigma-Aldrich) to eliminate endotoxins. Plasmid DNA pBluescript II-KS + (pBS; Stratagen, La Jolla, CA, USA) was purified with a commercial kit (Qiagen) and was further passed through a polymyxin-agarose column to eliminate endotoxins. Human placenta DNA was from Sigma-Aldrich. Phosphodiester ODNs (P-ODNs) or phosphorothioate ODNs (S-ODNs) were purchased from Sigma Genosys (The Woodlands, TX, USA) and Invitrogen Corporation (Rockville, MD, USA). The sequence of the CpG-containing ODN 2006 was TCGTCGTTTTGTCGTTTTGTCGTT. The sequence of the ODN with CpG inverted dinucleotides 2006K was TGCTGCTTTTGTGCTTTTGTGCTT. All materials employed were sterile and endotoxin free.

\section{Neutrophil Isolation}

Blood samples were obtained from healthy donors by venipuncture of the forearm vein. Neutrophils were isolated from heparinized human blood by Ficoll-Hypaque gradient centrifugation and dextran sedimentation as previously described. ${ }^{6}$ Contaminating erythrocytes were removed by hypotonic lysis. After washing, the cells ( $>96 \%$ of neutrophils on May-Grunwald-Giemsa-stained cytopreps) were resuspended in RPMI 1640 supplemented with $5 \mathrm{mg} / \mathrm{ml}$ endotoxin-free human albumin, $100 \mathrm{U} / \mathrm{ml}$ penicillin and $100 \mu \mathrm{g} / \mathrm{ml}$ streptomycin (complete medium) or in PBS as indicated. Human albumin was employed to protein supplement medium instead of fetal calf serum in order to avoid possible effects produced by contaminating LPS of the DNA samples, because as we and others have demonstrated, under these conditions, LPS fails to activate neutrophils. ${ }^{6,26,27}$

\section{Endothelial Cell Culture and Transendothelial Migration Assay}

Human umbilical vein endothelial cells (HUVEC) were obtained according to the method of Jaffe et al. ${ }^{28}$ Cells were seeded on $1 \%$ gelatin-coated $25-\mathrm{cm}^{2}$ tissue culture flasks and identified by morphology and von Willebrand factor antibody (Immunotech, Marseille, France) binding. Cells were grown in RPMI 1640 medium supplemented with fetal bovine serum (FBS; 10\%; Gibco, Rockville, MD, USA), heparin $(100 \mu \mathrm{g} / \mathrm{ml})$, endothelial cell growth factor supplement $(50 \mu \mathrm{g} / \mathrm{ml})$, sodium pyruvate $(2 \mathrm{mM})$, L-glutamine $(2 \mathrm{mM})$, penicillin $(100 \mathrm{U} / \mathrm{ml})$ and streptomycin $(100 \mu \mathrm{g} / \mathrm{ml})$ at $37^{\circ} \mathrm{C}$ in a humidified $5 \% \mathrm{CO}_{2}$ incubator. Having reached confluence, cells were detached by mild treatment with trypsin/ EDTA $(0.05 \%$ and $0.1 \mathrm{mM}$, respectively), washed with $10 \%$ FBS-supplemented PBS $\left(\mathrm{Ca}^{2+}\right.$ - and $\mathrm{Mg}^{2+}$ free; PBS/FBS) and seeded over filters bearing $3-\mu \mathrm{m}$ pore in Transwell culture plate inserts (Costar, Cambridge, MA, USA), pretreated with $0.01 \%$ gelatin $24 \mathrm{~h}$ before seeding and $60 \mu \mathrm{g} / \mathrm{ml}$ fibronectin $2 \mathrm{~h}$ before being used as previously described. ${ }^{29}$ After 5 days of culture, HUVEC monolayers were activated with $10 \mathrm{ng} / \mathrm{ml} \mathrm{TNF-} \alpha$ for $24 \mathrm{~h}$ at $37^{\circ} \mathrm{C}$. Then, neutrophils $\left(5 \times 10^{5}\right.$ in $\left.100 \mu \mathrm{l}\right)$ were seeded onto the upper chamber of the Transwell and allowed to migrate for $3 \mathrm{~h}$ at $37^{\circ} \mathrm{C}$. Neutrophils that reached the lower compartment were collected and evaluated for DNA binding.

\section{E. coli DNA Biotinylation}

E. coli DNA and pBS were biotinylated with Photoprobe (long arm) biotin (Vector Laboratories, Burlingame, CA, USA) by thermal coupling or photocoupling according to manufacturer's instructions. A 4:1 DNA:biotin ratio (w:w) was employed. 


\section{Cell Surface DNA Binding}

Neutrophils $\left(5 \times 10^{6}\right.$ per $\left.\mathrm{ml}\right)$ suspended in PBS with $5 \mathrm{mg} / \mathrm{ml}$ HSA (assay buffer) were incubated with the indicated concentrations of biotinylated-E. coli single stranded DNA (biot-DNA) at $4^{\circ} \mathrm{C}$ for $30 \mathrm{~min}$. Nonspecific binding was determined by preincubating cells with $10 \times$ E. coli single stranded DNA (ssDNA). After a 30-min incubation period, cells were washed with cold PBS and incubated for $10 \mathrm{~min}$ at $4^{\circ} \mathrm{C}$ in the dark with avidin DCS-FITC $(10 \mu \mathrm{g} / \mathrm{ml}$; Vector Laboratories) in assay buffer. After washing with cold PBS, cell surface DNA binding was analyzed by FACScan and confocal laser scanning microscopy (CLSM).

\section{Confocal Laser Scanning Microscopy}

A confocal laser scanning microscope (Carl Zeiss LSM510Axiovert 100M) was used to visualize the interaction between neutrophils and bacterial DNA. Neutrophils and biot-DNA were incubated and revealed with avidin-FITC as described above. The DNA binding to the cell surface was observed in chambered coverglass slides containing a borosilicate glass base of $170 \mu \mathrm{m}$ thickness (Lab-Tek Nunc no. 155411). Confocal images were reconstructed using the Zeiss LSM Image Browser Version 3.2.0. The images were acquired by sequentially scanning with settings optimal for FITC ( $488 \mathrm{~nm}$ excitation with argon laser line and detection of emitted light between 505 and $530 \mathrm{~nm}$; pseudocoloured green). A C-Apochromat $\times 63 / 1.2$ water immersion objective was used.

\section{E. coli DNA Digestion}

E. coli DNA was partially digested with $2 \mathrm{U}$ of DNase RQ1 (Promega) per mg of DNA by incubation at $37^{\circ} \mathrm{C}$ for $0,2,5$, 20, 80 and $1000(\mathrm{ON}) \mathrm{min}$. Then, DNase was inactivated by heating at $95^{\circ} \mathrm{C}$ for $10 \mathrm{~min}$ and the reaction products were dialyzed against $\mathrm{NaCl} 0.15 \mathrm{M}$, EDTA $1 \mathrm{mM}$ at room temperature and then quantified by determining absorbance at $260 \mathrm{~nm}$. Fragments were visualized on $0.8 \%$ denaturing agarose gel electrophoresis containing $50 \mathrm{mM} \mathrm{NaOH}$ and on $5 \%$ denaturing polyacrylamide gel containing urea $7 \mathrm{M}$ in TAE buffer. The size of the DNA fragments obtained was estimated by comparison with a set of DNA size markers in the $0.8 \%$ denaturing agarose gel (for fragments obtained after 0,2 or $5 \mathrm{~min}$ of digestion) or in $5 \%$ polyacrylamide gel (for fragments obtained after $20 \mathrm{~min}$ of degradation) by analyzing the line profile plots of each lane (ImageJ, NIH). The size ranges of fragments obtained in each digestion were calculated by excluding $10 \%$ of the sample mass at the edges of each line profile plot.

\section{CpG Methylation of E. coli DNA}

For some experiments, E. coli DNA was methylated with $\mathrm{CpG}$ methylase SssI according to the manufacturer's instructions (New England BioLabs Inc., Beverly, MA, USA). Briefly, DNA was treated with $1 \mathrm{U}$ CpG methylase SssI per $\mu$ g DNA for $4 \mathrm{~h}$ at $37^{\circ} \mathrm{C}$ in NE Buffer 2 supplemented with $160 \mu \mathrm{M}$ S-adenosylmethionine, and replenishment of S-adenosylmethionine after $2 \mathrm{~h}$. Methylation status was verified by digestion with HpaII and electrophoresis on $1 \%$ agarose gels, as described. ${ }^{30,31}$

\section{Measurement of IL-8 Production}

Neutrophils suspended in complete medium $\left(5 \times 10^{6}\right.$ per ml $)$ were seeded into round-bottom 96 -well plates and were stimulated with the indicated concentrations of E. coli DNA, digested DNA, ds pBS or medium (control), and cultured for $3 \mathrm{~h}$ at $37^{\circ} \mathrm{C}$. Culture supernatants were collected and IL-8 concentration was measured by ELISA ( $\& D$, Minneapolis, MN, USA). IL-8 released to culture supernatants was neosynthesized and did not represent a cytokine released from a preformed pool. It was suggested by the fact that stimulation of neutrophils with E. coli DNA in the presence of Actinomycin D abrogated IL-8 release to culture supernatants, indicating that it required de novo mRNA synthesis (data not shown).

\section{Neutrophil Treatment with Proteolytic Enzymes}

Neutrophils $\left(5 \times 10^{6}\right.$ per $\left.\mathrm{ml}\right)$ suspended in PBS were treated with $100 \mu \mathrm{g} / \mathrm{ml}$ trypsin or prot $\mathrm{K}$ for $30 \mathrm{~min}$ at room temperature. After three washes with PBS supplemented with $10 \mathrm{mg} / \mathrm{ml} \mathrm{HSA}$, E. coli DNA binding or IL-8 production in response to DNA was determined as previously described. The degree of cell surface proteolysis was monitored by evaluating the expression of CD16, a marker susceptible to the action of proteases, by immunostaining and flow cytometry.

\section{Statistical Analysis}

Statistical significance was determined using the nonparametric Wilcoxon or Friedman test for multiple comparisons with Dunn's post-test. Statistical significance was defined as $P<0.05$.

\section{RESULTS \\ DNA Binding to Human Neutrophil Surface}

We have previously determined that pretreatment of neutrophils with chloroquine and wortmannin, compounds that inhibit endosome acidification/maturation, does not affect the ability of bacterial DNA to induce neutrophil activation. In agreement with these findings, we also found that bacterial DNA immobilization does not modify its neutrophil stimulating capacity, suggesting that a cell surface molecule might be involved in the activation process. ${ }^{6}$ Thus, to further analyze the mechanism involved in neutrophil activation by bacterial DNA, we first evaluated the ability of bacterial DNA to interact with neutrophil surfaces by determining the binding of biot-DNA. Preliminary experiments indicated that biot-DNA effectively triggered IL-8 production by human neutrophils, suggesting that biotinylation did not impair DNA ability to induce neutrophil activation (data not shown). Thus, cells were incubated for $30 \mathrm{~min}$ at $4^{\circ} \mathrm{C}$ with $60 \mu \mathrm{g} / \mathrm{ml}$ biot-DNA, a concentration that has been previously 
shown to clearly induce neutrophil activation. ${ }^{6}$ After the addition of FITC-avidin, binding was revealed by flow cytometry (Figure 1a) or laser confocal microscopy analysis (Figure 1b). Results showed that neutrophils effectively bind bacterial DNA. As these assays were performed at $4^{\circ} \mathrm{C}$, the detected fluorescence represented biot-DNA binding to neutrophil surfaces. This fact was confirmed by the ability of trypan blue to completely quench the fluorescence emitted by neutrophils, which had bound biot-DNA (Figure 1a). Binding of DNA was independent of the presence of $\mathrm{Ca}^{2+}$ and
$\mathrm{Mg}^{2+}$ because no differences were detected when binding was achieved in PBS supplemented with both cations or in PBS plus EDTA $1.5 \mathrm{mM}$ (Figure 1c). Furthermore, binding was not modified when it was evaluated in PBS supplemented with FBS or with HSA (Figure 1d). Of note, our previous results indicated that bacterial DNA was equally efficient to activate neutrophils suspended in culture medium, PBS supplemented with $\mathrm{Ca}^{2+}$ and $\mathrm{Mg}^{2+}$, PBS with EDTA and in the presence or absence of FBS or HSA, suggesting that conditions under which bacterial DNA binding takes

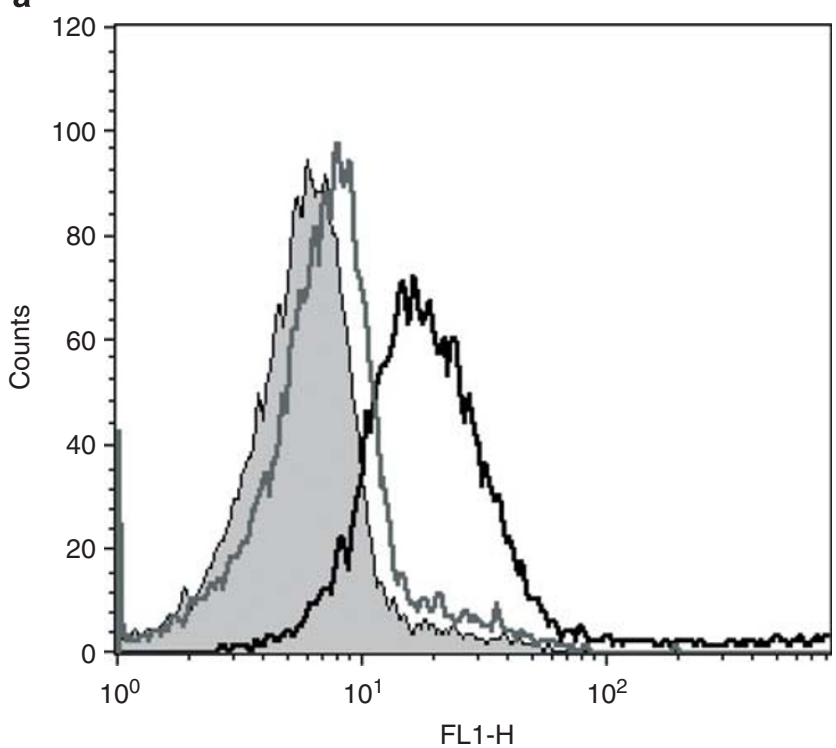

C

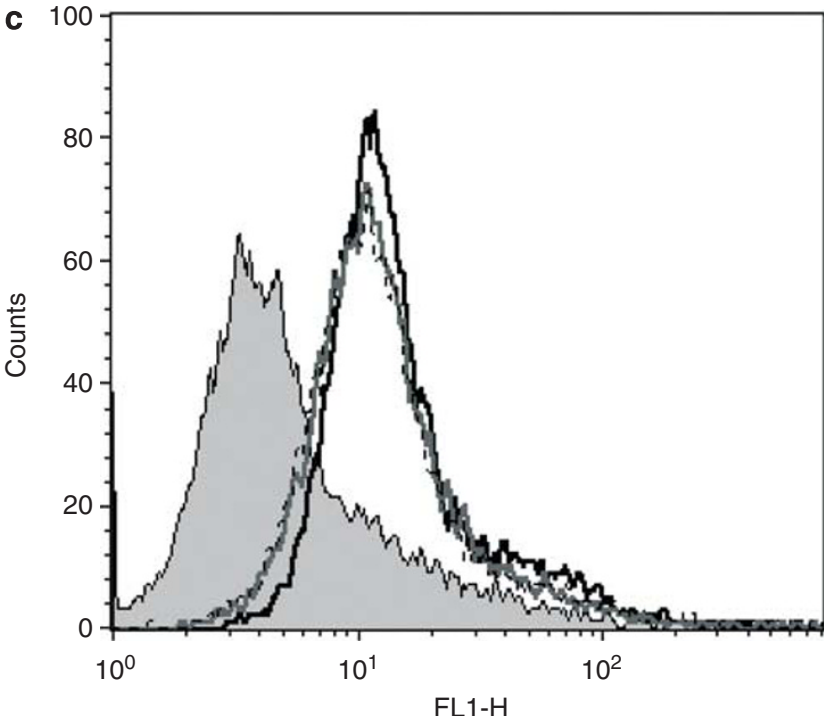

b
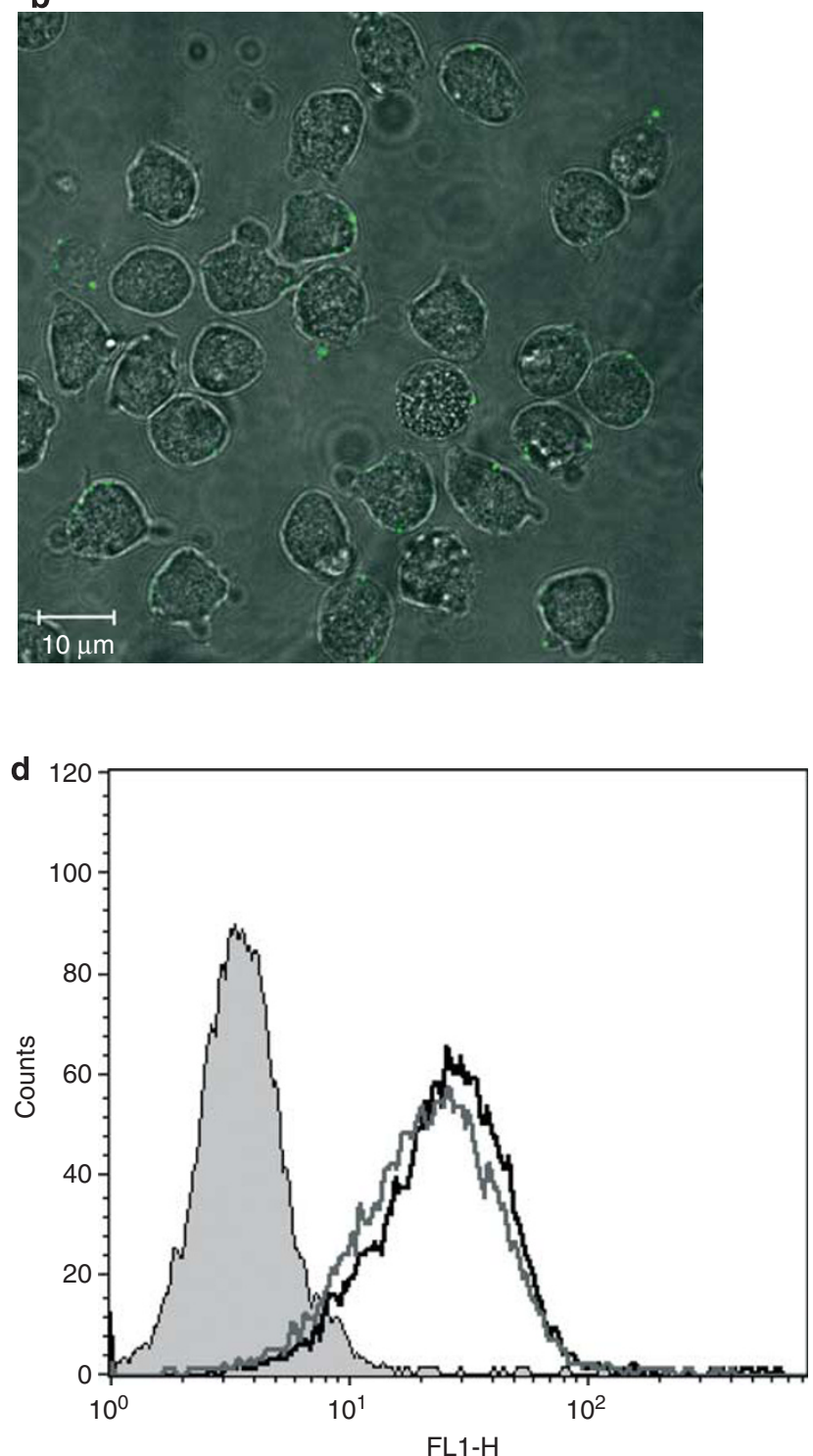

Figure 1 Binding of bacterial DNA to human neutrophils. (a) Neutrophils $\left(5 \times 10^{6}\right.$ per ml) were incubated in the presence (black line) or absence (shaded histogram) of single stranded biotinylated-E. coli DNA (biot-DNA; $60 \mu \mathrm{g} / \mathrm{ml}$ ) for $30 \mathrm{~min}$ at $4{ }^{\circ} \mathrm{C}$. After washing, binding was revealed by the addition of avidin-FITC by flow cytometry. Gray line represents the fluorescence after the addition of trypan blue. (b) Neutrophils treated as in (a) were evaluated by CLSM. Magnification $\times 630$. (c) Binding of biot-DNA in PBS (black line), PBS supplemented with $1 \mathrm{mM} \mathrm{CaCl} 2$ and $1 \mathrm{mM} \mathrm{MgCl} 2$ (gray line) or in PBS with EDTA $1.5 \mathrm{mM}$ (dashed line). (d) Binding of biot-DNA in PBS supplemented with HSA (black line) or in PBS supplemented with FBS (gray line). Shaded histograms represent fluorescence in the absence of biot-DNA. Histograms are representative of at least four independent experiments. 
place match with those required to trigger cell activation. ${ }^{6}$ Based on the above described results, the rest of the experiments were performed in PBS supplemented with HSA.

To determine whether bacterial DNA binding is saturable, we then incubated neutrophils with different concentrations of biot-DNA ranging from $3.5-120 \mu \mathrm{g} / \mathrm{ml}$. As shown in Figure $2 \mathrm{a}$, the binding curve showed saturation of bacterial DNA binding at $\approx 60 \mu \mathrm{g} / \mathrm{ml}$. The amount of DNA required to attain $50 \%$ of maximal biot-DNA binding was $17 \pm 4 \mu \mathrm{g} / \mathrm{ml}$. To test the specificity of the binding, cells were preincubated with different concentrations of unlabeled competitors (ssDNA, double stranded DNA (dsDNA), polyA, yeast tRNA or human DNA) and then incubated with $60 \mu \mathrm{g} / \mathrm{ml}$ of biot-DNA. A 10 -fold excess of unlabeled ssDNA reduced biot-DNA binding by $\sim 85 \%$ whereas the same excess of unlabeled dsDNA inhibited biot-DNA binding but less efficiently than ssDNA (Figure 2b). By contrast, poly-A and yeast tRNA were unable to reduce biot-DNA binding (Figure 2b). Interestingly, human DNA also displaced bacterial ssDNA binding similarly to what was observed with bacterial dsDNA, even though human DNA does not activate human neutrophils. ${ }^{6}$ Although our findings do not rule out the possibility that human DNA is competing with biot-DNA for binding to the same putative receptor, considering that human DNA is unable to induce neutrophil activation, it is also possible that it exerts a steric hindrance in bacterial DNA binding to neutrophils by interacting nonspecifically with the cell surface. Taken together, findings depicted in Figure $2 \mathrm{a}$ and $\mathrm{b}$ suggest that bacterial DNA binding is a receptor-mediated event.

Considering that our previous studies showed that P-ODNs either containing or lacking CpG motifs do not induce neutrophil activation whereas S-ODNs activate neutrophils independently of the presence of $\mathrm{CpG}$ motifs, we determined their ability to compete biot-DNA binding to cell surface. Results in Figure 2c show that P-ODNs did not significantly inhibit biot-DNA binding even employed at 10 -fold higher concentrations than biot-DNA, indicating that P-ODNs have a lower avidity than large DNA molecules to bind to neutrophil surface. Regarding S-ODNs, we found that S-ODN 2006 inhibited biot-DNA binding to neutrophil surface at all concentrations tested whereas S-ODN 2006K exerted variable effects depending on the concentration used (Figure 2c).

To characterize the nature of the putative DNA receptor, we then evaluated biot-DNA binding on neutrophils previously treated with trypsin or prot K. Figure 3a shows that cell treatment with proteases markedly inhibited biot-DNA binding, suggesting a role for a surface protein in DNA binding. The effectiveness of protease treatment was corroborated by evaluating the expression of CD16, a surface molecule which undergoes cleavage by the action of proteases. ${ }^{32}$ We also observed a direct relationship between the inhibition of bacterial DNA binding to the surface of protease-treated neutrophils and the susceptibility of these cells to be activated by bacterial DNA. As Figure $3 \mathrm{~b}$ shows, IL-8
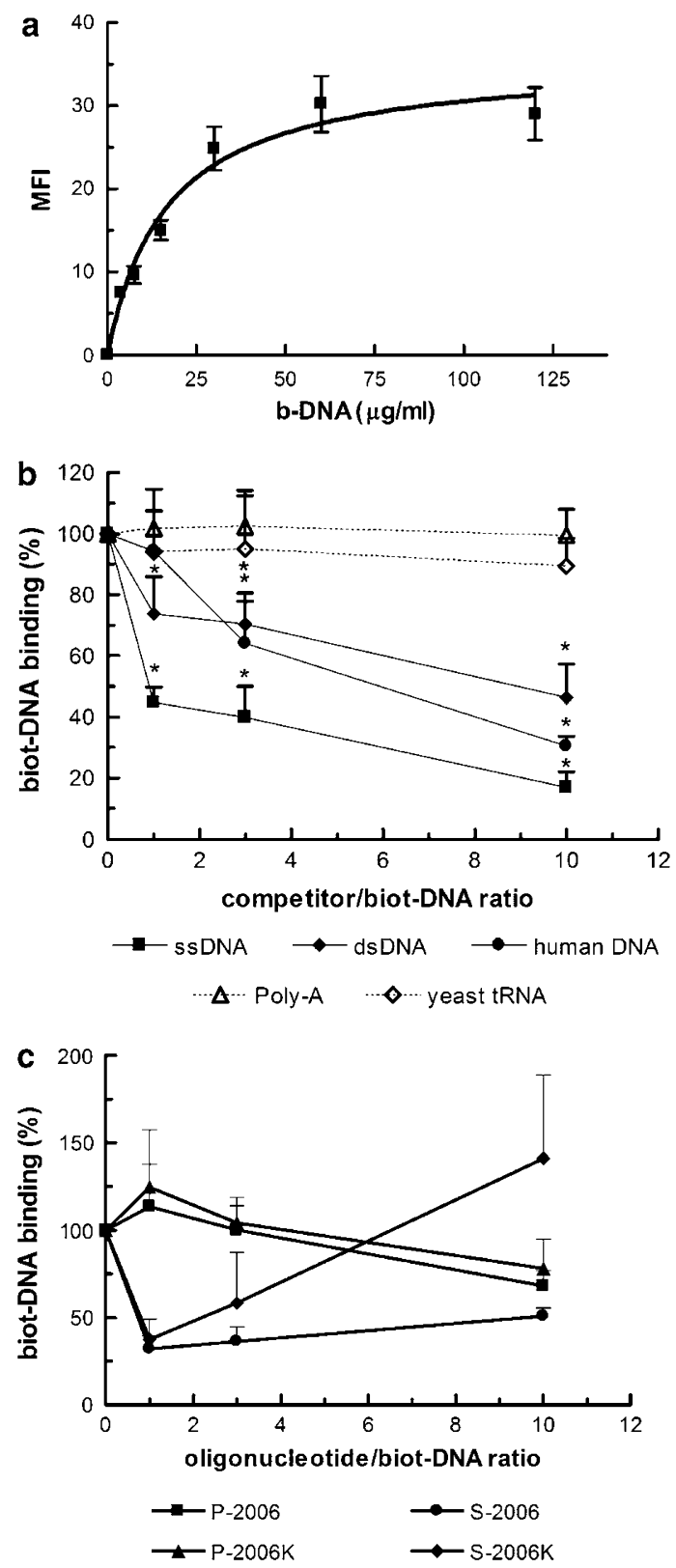

Figure 2 DNA-binding curve of bacterial DNA to neutrophil surface. (a) Neutrophils $\left(5 \times 10^{6}\right.$ per $\left.\mathrm{ml}\right)$ were incubated in the presence of $0,3.5,7$, $15,30,60$ or $120 \mu \mathrm{g} / \mathrm{ml}$ of biot-DNA for $30 \mathrm{~min}$ at $4^{\circ} \mathrm{C}$. After washing, binding was revealed by the addition of avidin-FITC by flow cytometry. Data represent the mean \pm s.e.m. of five experiments. (b) Neutrophils $\left(5 \times 10^{6}\right.$ per $\left.\mathrm{ml}\right)$ were incubated in the presence of $60(1 \times), 180(3 \times)$ or $600 \mu \mathrm{g} / \mathrm{ml}(10 \times)$ of cold ssDNA, cold dsDNA, sonicated cold human placenta DNA, poly-A or yeast tRNA during $20 \mathrm{~min}$ at $4^{\circ} \mathrm{C}$ or alternative (c) they were incubated in the presence of $60(1 \times), 180(3 \times)$ or $600 \mu \mathrm{g} / \mathrm{ml}$ $(10 \times)$ of cold ODNs P-2006, P-2006K, S-2006 or S-2006K for $20 \mathrm{~min}$ at $4^{\circ} \mathrm{C}$. Then, neutrophils were incubated for additional $30 \mathrm{~min}$ in the presence of $60 \mu \mathrm{g} / \mathrm{ml}$ of biot-DNA. After washing, binding was revealed by the addition of avidin-FITC by flow cytometry. Results are expressed as percentage of the maximal biot-DNA binding observed in the absence of competitors considered as $100 \%$. Data represent the mean \pm s.e.m. of $4-8$ experiments. ${ }^{\star} P<0.05$ vs biot-DNA binding in the absence of competitors. 

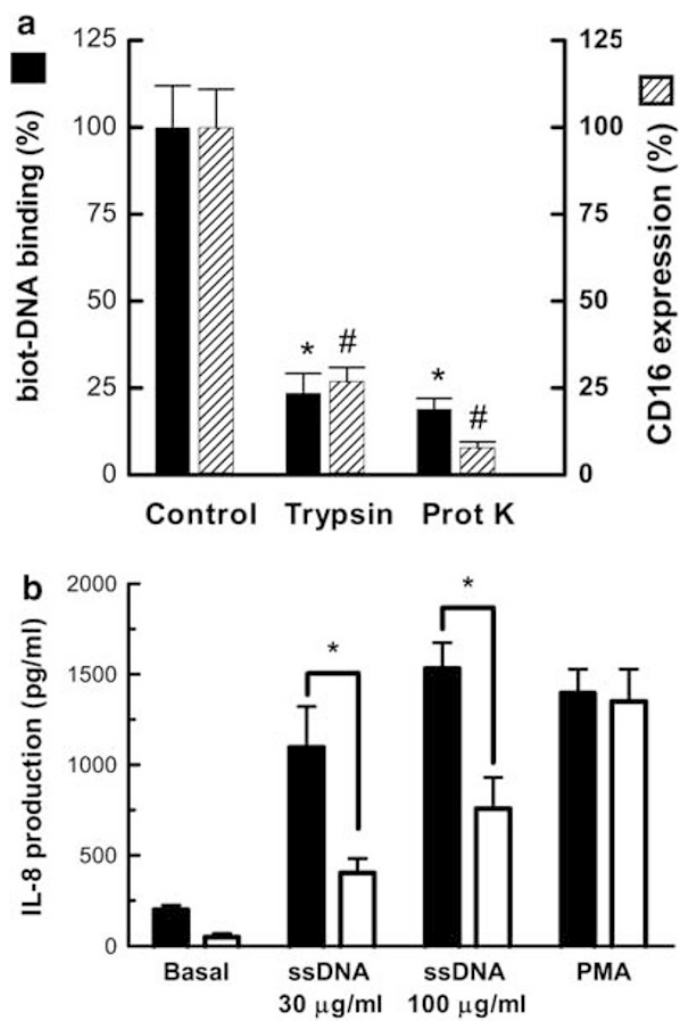

Figure 3 Neutrophil DNA binding is protease sensitive. (a) Neutrophils $\left(5 \times 10^{6}\right.$ per $\left.\mathrm{ml}\right)$ were incubated in the presence or absence of $100 \mu \mathrm{g} / \mathrm{ml}$ proteinase $\mathrm{K}$ (prot $\mathrm{K}$ ) or trypsin during $30 \mathrm{~min}$ at room temperature. Then, they were washed three times with PBS supplemented with $10 \mathrm{mg} / \mathrm{ml} \mathrm{HSA}$, and binding of biot-DNA and the expression of CD16 was evaluated. Results are expressed as percentage of biot-DNA binding or percentage of CD16 expression observed in cells not treated with proteases, considered as $100 \%$. Data represent the mean \pm s.e.m. of five experiments. ${ }^{*} P<0.01$ vs binding in cells not treated with the corresponding protease, ${ }^{\#} P<0.01$ vs CD16 expression in cells not treated with the corresponding protease. (b) Neutrophils were left untreated (black bars) or treated with prot $\mathrm{K}$ (white bars) as described in (a) and after were incubated in the presence or absence of ssDNA or PMA $(10 \mathrm{ng} / \mathrm{ml})$ for $3 \mathrm{~h}$ at $37^{\circ} \mathrm{C}$. Then, the IL-8 released to supernatants was evaluated by ELISA. Data represent the mean \pm s.e.m. of five experiments. ${ }^{\star} P<0.05$ vs IL-8 production in cells not treated with prot K (control cells).

production triggered by bacterial DNA was markedly inhibited in neutrophils treated with prot $\mathrm{K}$ as compared to that observed in cells not treated with this protease. As expected, protease treatment did not affect IL-8 production induced by PMA, because this compound triggers cell activation without interacting with cell surface receptors (Figure 3b).

\section{Analysis of Bacterial DNA Properties Enabling its Recognition by Neutrophils}

To determine whether there is a relationship between the length of DNA and its binding avidity to neutrophil surface, we partially digested E. coli DNA with DNase I for different periods of time. Then we dialyzed and quantified the products, and evaluated the size of the obtained fragments by comparison to a set of DNA size markers in $0.8 \%$ denaturing agarose gel electrophoresis (for fragments obtained after 0, 2 or 5 min of digestion) or in $5 \%$ denaturing polyacrylamide gel electrophoresis (for fragments obtained after more than 20 min of degradation). For simplicity, the pattern of DNA degradation is only shown in a representative agarose gel (Figure 4a). We employed these DNA fragments of differing lengths in competition assays, evaluating their ability to prevent the binding of undigested biot-DNA to neutrophil surface. As Figure $4 \mathrm{~b}$ shows, samples containing fragments between 30 and 170 nucleotides even employed at a 10-fold excess than biot-DNA were unable to inhibit its binding to neutrophil surface. By contrast, fragments longer than 290 bases, used at 10-fold excess reduced biot-DNA binding by $\sim 60 \%$. Surprisingly, DNA samples containing fragments ranging from 50 to 390 bases enhanced, although not significantly, biot-DNA binding, whereas those containing fragments of $\approx 90-930$ exhibited a marked variability in their capacity to modify biot-DNA binding.

We then evaluated whether the length of bacterial DNA affected its ability to trigger cell activation by analyzing IL- 8 production induced by DNA samples of differing lengths. Results depicted in Figure 4c show both that only the DNA samples containing fragments longer than 170 bases induced IL-8 production, and that the samples enriched in fragments longer that 290 bases showed the highest ability to trigger IL-8 production.

As plasmid DNA is currently used in DNA immunization and gene therapy protocols, we wondered whether it might be able to bind and trigger neutrophil activation. Thus, we performed additional experiments using biotinylated double stranded plasmid DNA (ds pBS). Plasmid DNA both efficiently bound to neutrophil surface (Figure $5 \mathrm{a}$ ) and triggered IL-8 production (Figure $5 b$ ).

Considering that $\mathrm{CpG}$ methylation does not affect DNA ability to induce neutrophil activation, ${ }^{6}$ we speculated that it would not modify its ability to bind to neutrophil surface. To test this premise, we treated E. coli DNA with SssI methylase and then evaluated its ability to compete the binding of biotDNA. Results in Figure 5c show that methylated ssDNA was equally efficient as unmethylated ssDNA (ssDNA) to inhibit biot-DNA binding to neutrophil surface.

\section{Modulation of Bacterial DNA Binding to Neutrophil Surface by Stimulation with Conventional Agonists}

We then evaluated whether stimulation of neutrophils with conventional agonists affected their ability to bind bacterial DNA. To this end, human neutrophils were stimulated with either of two chemoattractants, FMLP $\left(5 \times 10^{-9} \mathrm{M}\right)$ or IL-8 $(5 \mathrm{nM})$, or with PMA $(20 \mathrm{ng} / \mathrm{ml})$, for 5,15 and $30 \mathrm{~min}$, and then their ability to bind bacterial DNA was analyzed by employing $120 \mu \mathrm{g} / \mathrm{ml}$ of biot-DNA. Results from flow cytometric assays depicted in Figure 6a-c show that neutrophil stimulation with these agonists markedly increased cell surface biot-DNA binding, a fact that was confirmed by CLSM analysis (Figure 6d-e). Furthermore, neutrophils pretreated 

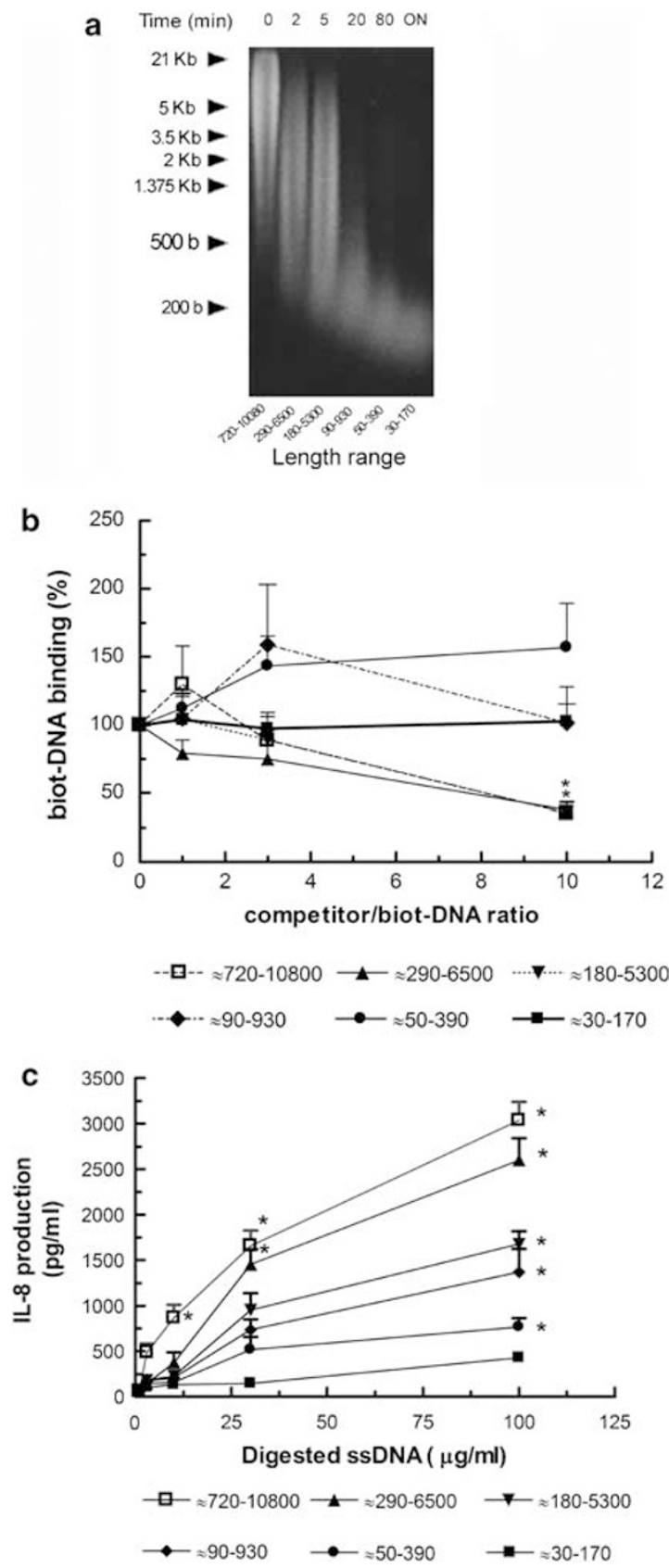

Figure 4 Identification of the minimal length of the oligomer able to bind to neutrophil surface. (a) Electrophoresis in $0.8 \%$ denaturating agarose gels of $E$. coli DNA treated with DNase RQ1 for the indicated times. (b) Neutrophils $\left(5 \times 10^{6}\right.$ per $\left.\mathrm{ml}\right)$ were incubated during $30 \mathrm{~min}$ at $4{ }^{\circ} \mathrm{C}$ in the presence or absence of 60 (ratio 1), 180 (ratio 3) or $600 \mu \mathrm{g} / \mathrm{ml}$ (ratio 10) of unlabeled fragments obtained after DNase digestion of bacterial DNA, for $20 \mathrm{~min}$ at $4^{\circ} \mathrm{C}$. Then, neutrophils were incubated for additional $30 \mathrm{~min}$ in the presence of $60 \mu \mathrm{g} / \mathrm{ml}$ of biot-DNA. After washing, binding was revealed by the addition of avidin-FITC by flow cytometry. Results are expressed as percentage of the maximal biot-DNA binding observed in the absence of competitors considered as $100 \%$. Data represent the mean \pm s.e.m. of six experiments. (c) Neutrophils $\left(5 \times 10^{6}\right.$ per $\left.\mathrm{ml}\right)$ were incubated during $3 \mathrm{~h}$ at $37^{\circ} \mathrm{C}$ in the presence or absence of the indicated concentrations of fragments obtained after DNase digestion of bacterial DNA. Then, IL-8 release to culture supernatant was evaluated by ELISA. Data represent the mean \pm s.e.m. of six experiments evaluated in triplicate. ${ }^{\star} P<0.05$ vs basal IL-8 production. with FMLP exhibited an enhanced capacity to produce IL-8 in response to bacterial DNA (Figure 6f), showing a direct relationship between the intensity of DNA binding and the level of cellular activation.

As expected, unlabeled ssDNA, but not poly-A, effectively inhibited the binding of biot-DNA to stimulated neutrophils (Figure $6 \mathrm{~g}-\mathrm{n}$ ), supporting that neutrophil activation results in an increased ability to specifically recognize bacterial DNA which is not related to an enhanced capacity to bind polyanions in a nonspecific manner.

Results from Figure $6 \mathrm{a}-\mathrm{c}$ show that the increase in bacterial DNA binding upon neutrophil activation was noticeable as early as $5 \mathrm{~min}$ post stimulation (the first time-point analyzed), indicating that it did not depend on de novo synthesis of a putative receptor. Thus, it could be accounted for by an increase in the expression of DNA receptors from a preexisting pool present in the membrane of granules that become part of plasma membrane due to granule exocytosis in response to stimulation with the above-described agonists. To test this hypothesis, neutrophils were treated with pentoxifylline (PXF, $5 \mathrm{mM}$ ), a methylxanthine derivative able to inhibit neutrophil degranulation, ${ }^{33}$ and then were stimulated with FMLP for $15 \mathrm{~min}$ at $37^{\circ} \mathrm{C}$. Afterwards, both the binding of biot-DNA and the expression of CD11b were evaluated. The expression of $\mathrm{CD} 11 \mathrm{~b}$ was determined to address the degree of inhibition of degranulation mediated by PXF treatment, because it is expressed in the membrane of specific and gelatinase granules as well as in secretory vesicles. ${ }^{34}$ Results from Figure 7 show that PXF inhibited in a similar fashion both the enhancement of biot-DNA binding (Figure 7, left $y$ axis) and the upregulation of CD11b expression in FMLP-treated neutrophils (Figure 7, right $y$ axis). Similar results were obtained when exocytosis of all four granule types was inhibited by incubation of neutrophils under hypertonic conditions (data not shown).

\section{Effect of Cell Migration on Bacterial DNA Binding to Neutrophil Surface}

It is well established that during extravasation to inflammatory foci, neutrophils undergo degranulation, an event that increases the expression of molecules involved in the adhesion cascade and diapedesis. Thus, we questioned whether transendothelial migration might modulate the DNA-binding capacity of human neutrophils. To address this issue, neutrophils were seeded on confluent monolayers of HUVECs cultured on Transwell filters, which had been previously activated by TNF- $\alpha$ treatment. Later, neutrophils were allowed to migrate across endothelial cells for $3 \mathrm{~h}$, and their ability to bind biot-DNA was determined. Transmigrated neutrophils showed a markedly increased capacity to bind biot-DNA as compared to nonmigrated neutrophils (Figure 8). Of note, we did not evaluate the DNA-binding capacity of neutrophils that transmigrate in response to chemoattracts because, as we had previously determined, these stimuli 
a

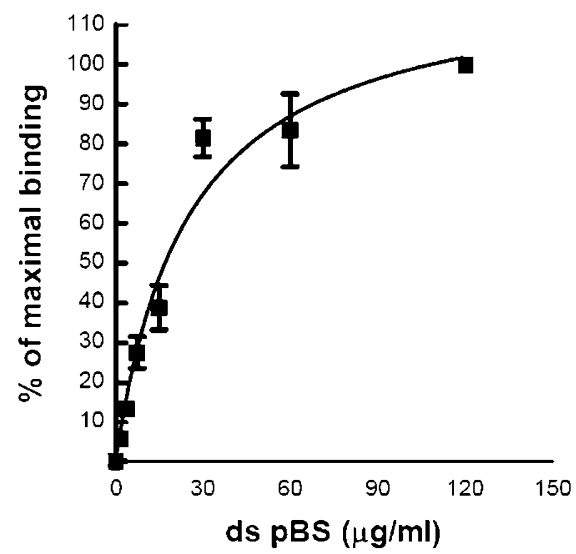

b

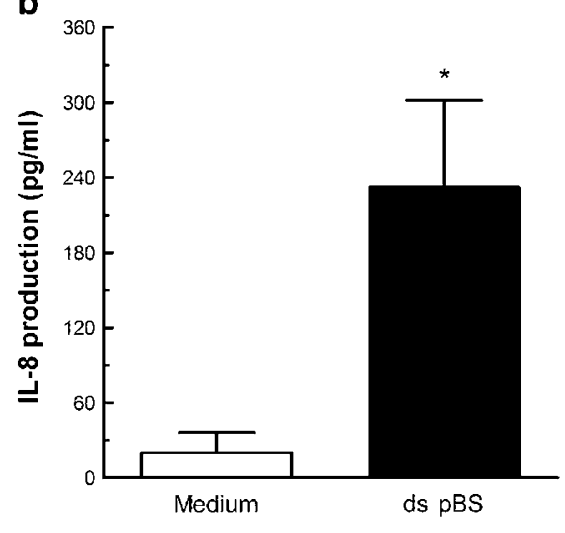

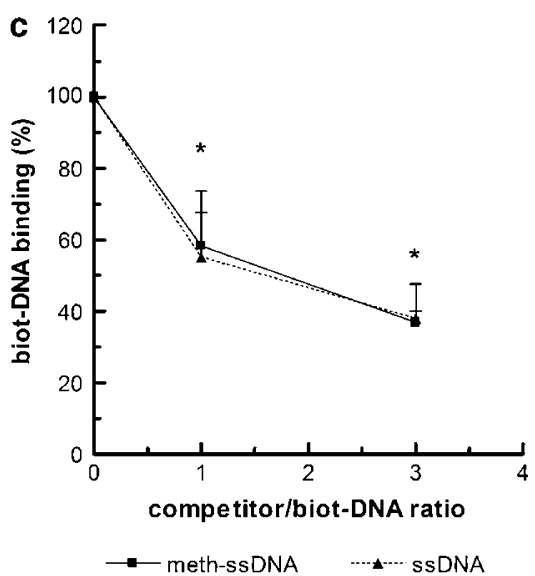

Figure 5 Plasmid DNA binding to neutrophil surface. (a) Neutrophils $\left(5 \times 10^{6}\right.$ per ml) were incubated in the presence of $1.9,3.8,7.5,15,30,60$, or $120 \mu \mathrm{g} / \mathrm{ml}$ of biotinylated double stranded plasmid DNA (ds pBS) for $30 \mathrm{~min}$ at $4^{\circ} \mathrm{C}$. After washing, binding was revealed by the addition of avidin-FITC by flow cytometry. (b) Neutrophils $\left(5 \times 10^{6}\right.$ per ml) were incubated for $3 \mathrm{~h}$ at $37^{\circ} \mathrm{C}$ in the presence or absence of ds pBS $(30 \mu \mathrm{g} / \mathrm{ml})$. Then, IL- $8 \mathrm{release}$ to culture supernatant was evaluated by ELISA. Data represent the mean \pm s.e.m. of three experiments. ${ }^{*} P<0.05$ vs absence of ds pBS. (c) Neutrophils $\left(5 \times 10^{6}\right.$ per ml) were incubated in the presence of $60(1 \times)$ or $180(3 \times) \mu \mathrm{g} / \mathrm{ml}$ of cold unmethylated-ssDNA or methylated-ssDNA for $20 \mathrm{~min}$ at $4^{\circ} \mathrm{C}$. Then, neutrophils were incubated for additional $30 \mathrm{~min}$ in the presence of $60 \mu \mathrm{g} / \mathrm{ml}$ of biot-DNA. After washing, binding was revealed by the addition of avidin- FITC by flow cytometry. Results are expressed as percentage of the maximal biot-DNA binding observed in the absence of competitors considered as $100 \%$. Data represent the mean \pm s.e.m. of 4-8 experiments.

significantly increase per se the neutrophil ability to bind DNA.

\section{DISCUSSION}

In this study we determined that bacterial DNA binds to human neutrophil surface. Binding was saturable and was dose-dependently inhibited by competition with an excess of unlabeled DNA but not by other polyanions like poly-A or yeast tRNA, suggesting that it is a receptor-mediated process. Binding was prevented by previous treatment of cells with trypsin or prot $\mathrm{K}$, and this effect was associated to an incapacity of neutrophils to produce IL-8 in response to bacterial DNA, strongly suggesting that DNA binds to a protease-sensitive specific surface receptor.

Previous studies performed by Bennett et $a l^{35}$ supported the presence of a DNA-binding receptor on neutrophil plasma membrane which would be responsible for the endocytosis and degradation of exogenous DNA. Contrasting with our findings, they found that binding of $\lambda$-phage DNA to neutrophils was dependent upon the presence of calcium and magnesium as well as sulfates. The reasons for these discrepancies could be due to differences in the origin of DNA assessed or to distinct experimental settings employed. In fact, Bennett et al used $\left[{ }^{3} \mathrm{H}\right]$-DNA and evaluated binding to neutrophils pretreated for an hour with DNase, a procedure that could have activated cells by integrin-mediated interactions and modified the DNA-binding properties of neutrophils.

Other works have also determined the presence of DNA binding proteins in leukocytes, fibroblasts, keratinocytes and Kupffer cells. ${ }^{36-40}$ It has been reported that an $80 \mathrm{kDa}$ protein mediates the transport of ODNs in HL-60 cells. ${ }^{36}$ The authors reported that ODNs binding was sequence independent and could be inhibited by $60-80 \%$ by twofold excess $(25 \mu \mathrm{M})$ of unlabeled ODNs, as well as by desoxyribonucleotides, ribonucleotides, plasmid DNA and yeast tRNA. However, the 

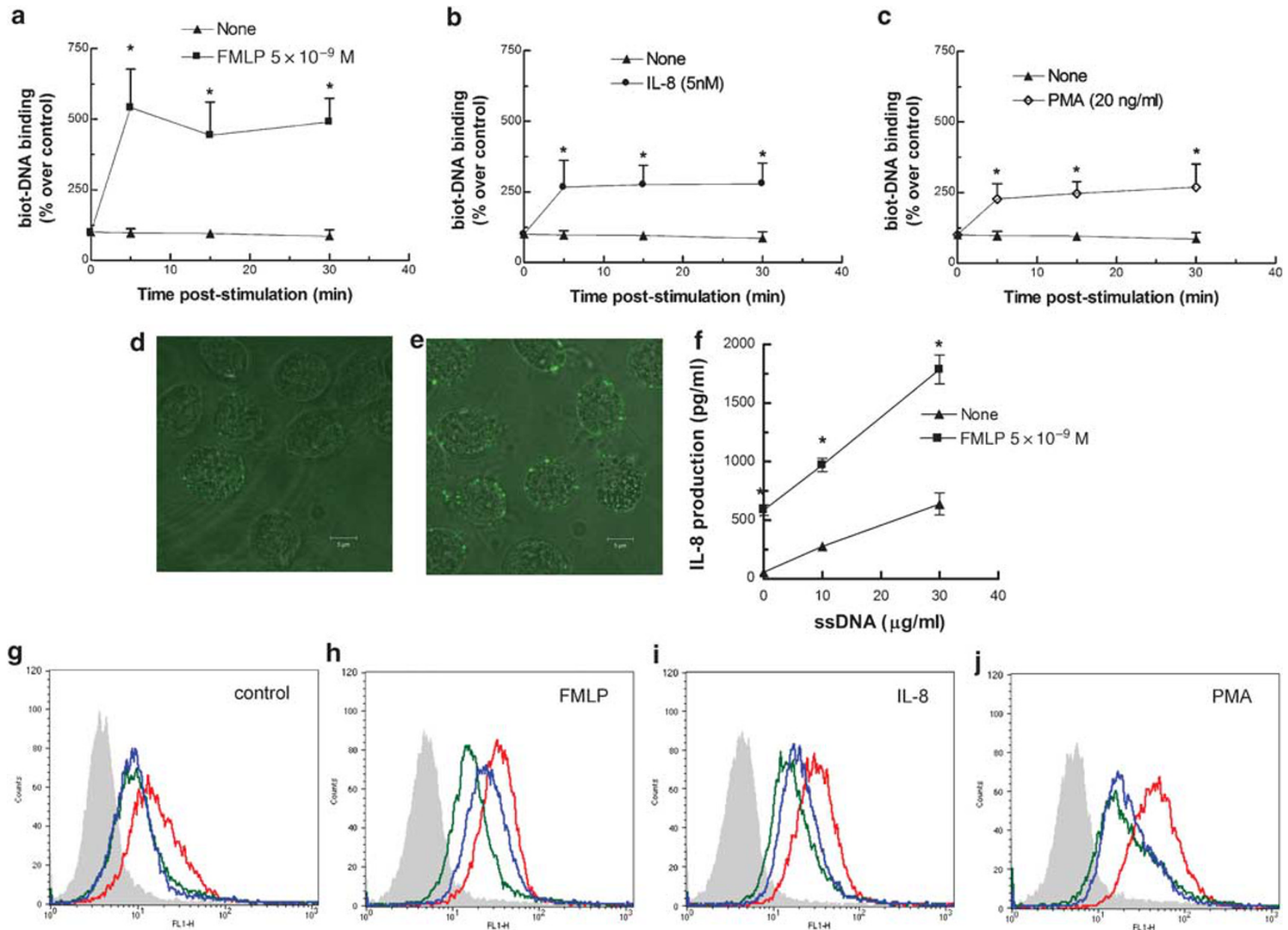

h
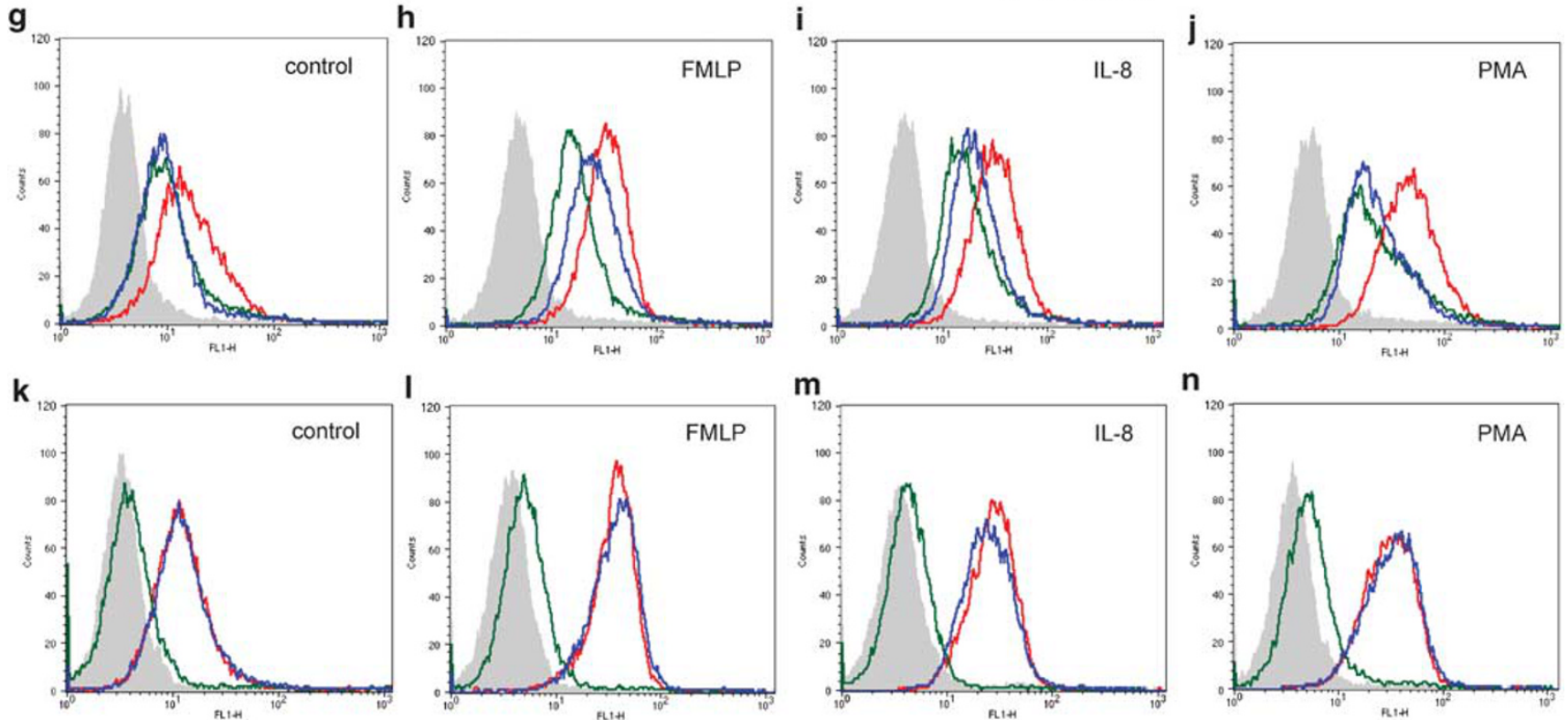

Figure 6 Neutrophil activation increases binding of bacterial DNA. (a-c) Neutrophils $\left(5 \times 10^{6}\right.$ per ml) were incubated in the presence or absence of $5 \times 10^{-9}$ M FMLP, $5 \mathrm{nM} \mathrm{IL}-8$ or $20 \mathrm{ng} / \mathrm{ml} \mathrm{PMA} \mathrm{during} \mathrm{the} \mathrm{indicated} \mathrm{periods} \mathrm{of} \mathrm{time,} \mathrm{and} \mathrm{then,} \mathrm{binding} \mathrm{was} \mathrm{analyzed} \mathrm{by} \mathrm{employing} 120 \mu \mathrm{g} / \mathrm{ml}$ biot-DNA. (d, e) Confocal laser scanning microscopy (CLSM) images of neutrophils incubated in the absence (d) or presence of $5 \times 10^{-9} \mathrm{M} \mathrm{FMLP}(\mathbf{e})$ during 15 min at $37^{\circ} \mathrm{C}$ and then for $30 \mathrm{~min}$ at $4^{\circ} \mathrm{C}$ with $120 \mu \mathrm{g} / \mathrm{ml}$ biot-DNA followed by FITC-avidin; magnification $\times 630$. (f) Neutrophils $\left(5 \times 10^{6}\right.$ per ml) were incubated in the presence or absence of $5 \times 10^{-9} \mathrm{M} \mathrm{FMLP}$ for $15 \mathrm{~min}$ at $37^{\circ} \mathrm{C}$ and then stimulated with the indicated ssDNA concentrations during additional $3 \mathrm{~h}$ at $37^{\circ} \mathrm{C}$. Then, IL-8 released to supernatants was evaluated by ELISA. Data represent the mean \pm s.e.m. of five experiments; ${ }^{\star} P<0.05$ vs IL-8 production in cells not stimulated with FMLP. $(\mathbf{g}-\mathbf{n})$ Neutrophils $\left(5 \times 10^{6}\right.$ per $\left.\mathrm{ml}\right)$ were incubated in the presence or absence of the indicated agonists for 15 min at $37^{\circ} \mathrm{C}$. Then, they were incubated in the presence or absence of a fivefold excess of cold ssDNA $(\mathbf{g}-\mathbf{j})$ or $1.2 \mathrm{mg} / \mathrm{ml} \mathrm{poly-A}(\mathbf{k}-\mathbf{n})$, during $20 \mathrm{~min}$ at $4{ }^{\circ} \mathrm{C}$. Then, without being washed, neutrophils were incubated for additional $30 \mathrm{~min}$ in the presence of $120 \mu \mathrm{g} / \mathrm{ml}$ of biot-DNA. After washing, binding was revealed by the addition of avidin-FITC by flow cytometry. Histograms are representative of at least four experiments. Shaded histograms represent nonspecific binding of avidin-FITC, nonspecific avidin-FITC binding to unlabeled DNA or poly-A (green line), biot-DNA binding of neutrophils incubated in the absence (control) or presence the indicated agonists (red line) and biot-DNA binding of neutrophils preincubated in the absence (control) or presence of the indicated agonists and then incubated with fivefold excess of unlabeled DNA $(\mathbf{g}-\mathbf{j})$ or poly-A (k-n) (blue line).

binding of DNA and the activation of neutrophil described here do not appear to be mediated by this protein, because our results shown that (1) DNAs smaller than 170 nucleo- tides neither significantly competed binding of undigested biot-DNA to neutrophils nor were able to induce their activation and (2) yeast tRNA and poly-A were completely 


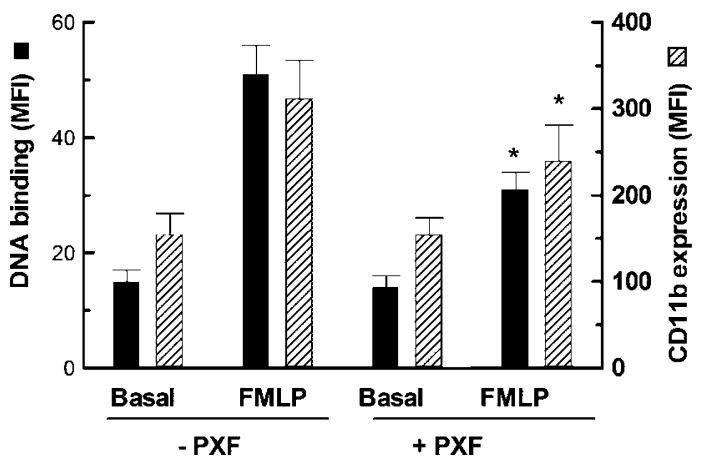

Figure 7 Inhibition of degranulation significantly reduces the increase of bacterial DNA binding observed after neutrophil stimulation. Neutrophils $\left(5 \times 10^{6}\right.$ per $\left.\mathrm{ml}\right)$ were incubated in the presence or absence of $5 \mathrm{mM} \mathrm{PXF}$, then were stimulated or not with $5 \times 10^{-9} \mathrm{M} \mathrm{FMLP}$ during $15 \mathrm{~min}$ at $37^{\circ} \mathrm{C}$. After, binding of biot-DNA (left axis) and expression of CD11b (right axis) was evaluated by FACscan. Data represent the mean \pm s.e.m. of five experiments. ${ }^{*} P<0.05$ vs FMLP-stimulated cells incubated in the absence of PXF.

unable to inhibit bacterial DNA binding to neutrophils. Other two DNA-binding proteins (79 and $90 \mathrm{kDa}$ ) have been detected in L929 mouse fibroblasts. ${ }^{37}$ In human keratinocytes, two plasma membrane-actin linkers, ezrin and moesin, were identified as DNA-binding proteins. ${ }^{38}$ Using southwestern analysis and gel shift and supershift assays, the authors found that these proteins were able to bind plasmid DNA, $\lambda$-phage DNA, ODNs irrespective of their sequences and calf thymus DNA, but not RNA. On the other hand, Benimetskaya et $a^{39}$ demonstrated the ability of Mac-1 to bind ODNs. We have previously demonstrated, however, that this protein is not involved in bacterial DNA recognition by human neutrophils ${ }^{6}$ and recently confirmed these findings by evaluating bacterial DNA binding and its activating capacity in neutrophils of a patient suffering from leukocyte adhesion deficiency-1 (JI Fuxman Bass, unpublished results). The scavenger receptor A (SRA) has also been proposed to function as a DNAbinding molecule, although when cytokine production and DNA uptake by cells lacking the SRA were analyzed, similar levels to those of cells that express this receptor were detected, indicating that SRA, whereas able to bind DNA, is not essential for immune stimulation by DNA. ${ }^{41}$ Early studies in Kupffer cells have reported binding of calf thymus DNA fragments (250-350 bases) to a trypsin-sensitive receptor. ${ }^{40}$ In agreement with our study, they found that DNA binding was independent of serum factors. More recent work showed that RAW264.7 macrophages not only bind DNA but also their exposure for $18 \mathrm{~h}$ to DNA or LPS increases cell surface DNA binding and internalization. ${ }^{42}$ In contrast to our findings, these authors observed that PMA treatment of RAW264.7 macrophages did not increase DNA binding.

Our observations indicated that samples enriched in fragments shorter than 170 nucleotides did not affect undigested biot-DNA binding. These results, however, should be interpreted with caution, because they do not rule out that fragments shorter than 170 nucleotides might actually bind to neutrophils. Our smaller DNA samples contain distinct fragments ranging from 30 to 170 nucleotides, thus it is

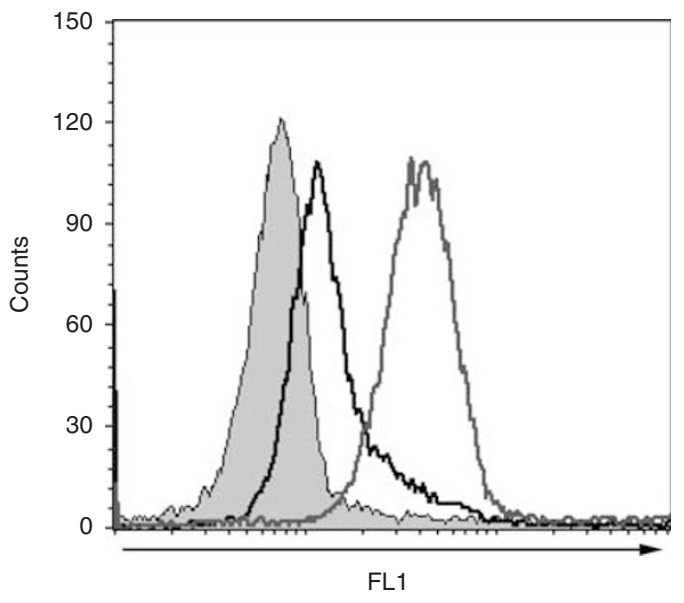

Figure 8 Neutrophil transmigration increases binding of bacterial DNA. Confluent monolayers of HUVECs cultured on Transwell filters were activated during $24 \mathrm{~h}$ with TNF- $\alpha(10 \mathrm{ng} / \mathrm{ml})$. Then, monolayers were washed to eliminate residual TNF- $\alpha$, and neutrophils $\left(5 \times 10^{5}\right.$ per well) were seeded on HUVECs and allowed to migrate for $3 \mathrm{~h}$ at $37^{\circ} \mathrm{C}$. Transmigrated cells were recovered and DNA binding was evaluated by employing $120 \mu \mathrm{g} /$ $\mathrm{ml}$ of biot-DNA as previously described, and compared to biot-DNA binding in cells incubated during the $3 \mathrm{~h}$ in the lower chamber of the transmigration system. Binding of biot-DNA on transmigrated neutrophils (gray line), on nonmigrated neutrophils (black line) and fluorescence in absence of biotDNA (shaded histogram). Histograms are representative of three independent experiments.

conceivable that a proportion of these fragments, perhaps those longest among the sample, can interact with the putative receptor although the binding of these fragments cannot be enough to be detected in competition assays. On the other hand, samples containing DNAs longer than 290 nucleotides triggered the highest levels of IL-8 production and were able to efficiently preclude binding of undigested biot-DNA, suggesting that this DNA length is critical for both efficient binding and activation, a fact that might reflect an increase in the affinity/avidity of the putative receptor if DNA has a length that allows it to interact simultaneously with two or more receptors.

Remarkably, DNAs ranging from 50 to 390 nucleotides enhanced biot-DNA binding whereas those ranging from 90 to 930 -mers showed a variable behavior, suggesting that some oligomers might facilitate DNA binding to neutrophil surface. Our data do not provide an answer as to how this binding-promoting effect might be brought about; however, similar findings were previously reported to occur in DNA binding to TLR9. Kindrachuk et $a l^{43}$ demonstrated that sequences that are unable to mediate direct activation of TLR9 influence TLR9 function by sensitizing the receptor for in vitro ligand binding as well as in vivo activation. Their studies indicated that ODNs promote plasmid binding to TLR9 without being incorporated into the complex TLR9plasmid. They also found that both CpG- and non-CpGphosphodiester ODNs were equally effective in promoting plasmid binding, but the phosphorothioate ODNs were far less effective in this capacity. We have not been able to detect 
facilitation of biot-DNA binding by small ODNs ( $\approx 24$-mer), however, further studies employing ODNs with different sequences are required to generalize this observation.

We also found that not only unlabeled ssDNA but also dsDNA and ss-meth-DNA inhibited binding of biot-DNA to neutrophil surface. These findings evidenced a direct relationship between DNA binding and activation, because we have previously shown that both dsDNA and ss-meth-DNA activate human neutrophils. ${ }^{6}$ Moreover, dsDNA was less efficient than ssDNA to competitively inhibit binding of biotDNA, in accordance with our previous findings indicating that dsDNA activates human neutrophils less effectively than ssDNA. ${ }^{6}$ Additionally, we showed here that plasmid DNA not only binds but also activate human neutrophils. These findings might reflect similarities in DNA-binding properties between the neutrophil surface putative DNA receptor and the canonical DNA receptor, TLR9, for which both binding of ssDNA as well as plasmid DNA, preferentially in a supercoiled state, has been demonstrated. ${ }^{43,44}$

Our results also indicated that human DNA is able to inhibit bacterial biot-DNA binding to cell surface. Although these findings do not rule out the possibility that human DNA is competing with biot-DNA for binding to the same putative receptor, considering that human DNA is unable to induce neutrophil activation, it is also possible that long human DNA molecules exert a steric hindrance in bacterial DNA binding to neutrophils by interacting nonspecifically with the cell surface. Another possibility could be that human DNA effectively binds to the same receptor as bacterial DNA does, but being unable to trigger cell activation. Supporting this possibility, previous studies on TLR9 function have shown that TLR9 binds to stimulatory and inhibitory DNA; however, only stimulatory DNA led to substantial conformational changes in the TLR9 ectodomain that results in the activation of transductional pathways. ${ }^{45}$ Irrespectively of the mechanisms through which human DNA interacts with neutrophil surface, the ability of human DNA to inhibit bacterial DNA binding might have consequences in vivo in reducing the proinflammatory capacity of bacterial DNA. In fact, recent studies have demonstrated the release of genomic DNA by neutrophils undergoing death by 'NETosis. ${ }^{46}$ During 'NETosis', neutrophils release extracellular traps (NETs), composed of chromatin and specific proteins from the neutrophilic granules. ${ }^{47}$ Considering that bacteria are potent stimulators of NETs formation, it is possible to speculate that human DNA contained in NETs might compete with bacterial DNA for binding to viable neutrophils, thus reducing its capacity to trigger inflammatory responses. Supporting this possibility, we have observed that a 10 -fold excess of human DNA significantly inhibited the production of IL-8 triggered by bacterial DNA (JI Fuxman Bass, unpublished results).

We also found that binding of bacterial DNA is markedly enhanced upon treatment of neutrophils with both chemoattractants and PMA. The increased capacity of neu- trophils to bind DNA was evidenced 5 min after stimulation, suggesting that it did not involve de novo synthesis of a putative receptor. By contrast, it probably accounted for an increased exposition of a DNA-binding protein from a preexisting pool present in the membrane of granules that become part of plasma membrane due to granule exocytosis in response to stimulation with the above-described agonists. This presumption was supported by findings indicating that the inhibitor of degranulation PXF, inhibited in a similar fashion both the upregulation of CD11b and the enhancement of DNA binding triggered by FMLP. However, our results do not rule out that the DNA-binding protein whose expression is increased upon neutrophil activation is not a DNA receptor responsible for activation but a protein able to bind DNA and consequently cooperate in DNA binding to a transducing receptor. In fact, previous studies demonstrated that lactoferrin, a cationic protein contained in specific granules, is mobilized to plasma membrane upon neutrophil activation $^{48}$ and exhibits DNA-binding properties. ${ }^{49}$ Moreover, we have also determined that myeloperoxidase and catepsin G, two cationic proteins contained in azurophilic granules, are able to bind DNA (JI Fuxman Bass, unpublished results). However, our results showing that the increase in bacterial DNA binding due to neutrophil stimulation with conventional agonists could be inhibited by competence with unlabeled DNA but not by another polyanion like poly-A, favor the view that neutrophil activation results in the expression of additional DNA-specific receptors.

Finally, we found that transmigration across confluent HUVECs monolayers markedly increases neutrophil DNAbinding capacity. It is possible to speculate that in a physiological setting, after extravasation, neutrophils are better prepared to recognize and be activated by bacterial DNA.

Extracellular DNA has been detected in virtually all environments inhabited by bacteria, ${ }^{16,18,19,50-52}$ and has also been implicated as a major structural component of bacterial biofilms. ${ }^{24,25,53}$ Thus, it is possible that bacterial DNA recognition by a surface receptor has evolved as a signal to alert the immune system to the presence of bacterial invasion, mainly in infections which course with bacteria growing as biofilms. Further studies are underway in our laboratory to identify the receptor responsible for DNA recognition.

\section{ACKNOWLEDGEMENTS \\ We thank Yanina Powazniak, Evelia López, Mabel Horvat and Beatriz Loria for their valuable assistance. We also thank Dr Tomás Santa Coloma for making confocal microscope available. This work was supported by grants from Agencia Nacional de Promoción Científica y Tecnológica (PICT20433), Consejo Nacional de Investigaciones Científicas y Técnicas (PIP6133), the Third World Academy of Sciences (RG 04-0389) and Fundación Alberto Roemmers (Argentina).}

1. Nathan C. Neutrophils and immunity: challenges and opportunities. Nat Rev Immunol 2006;6:173-182. 
2. Witko-Sarsat V, Rieu P, Descamps-Latscha B, et al. Neutrophils: molecules, functions and pathophysiological aspects. Lab Invest 2000;80:617-653.

3. Hemmi $\mathrm{H}$, Takeuchi $\mathrm{O}$, Kawai $\mathrm{T}$, et al. A Toll-like receptor recognizes bacterial DNA. Nature 2000:408:740-745.

4. Ishii KJ, Akira S. Innate immune recognition of, and regulation by, DNA. Trends Immunol 2006;27:525-532.

5. Kawai T, Akira S. TLR signaling. Cell Death Differ 2006;13:816-825.

6. Trevani AS, Chorny A, Salamone G, et al. Bacterial DNA activates human neutrophils by a CpG-independent pathway. Eur J Immunol 2003;33:3164-3174.

7. Alvarez ME, Fuxman Bass Jl, Geffner JR, et al. Neutrophil signaling pathways activated by bacterial DNA stimulation. J Immunol 2006;177:4037-4046.

8. Yoshinaga T, Yasuda K, Ogawa $\mathrm{Y}$, et al. Efficient uptake and rapid degradation of plasmid DNA by murine dendritic cells via a specific mechanism. Biochem Biophys Res Commun 2002;299: 389-394.

9. Wang Y, Krieg AM. Synergy between CpG- or non-CpG DNA and specific antigen for B cell activation. Int Immunol 2003;15:223-231.

10. Elias F, Flo J, Lopez RA, et al. Strong cytosine-guanosine-independent immunostimulation in humans and other primates by synthetic oligodeoxynucleotides with PyNTTTTGT motifs. J Immunol 2003;171:3697-3704.

11. Yasuda K, Yu P, Kirschning CJ, et al. Endosomal translocation of vertebrate DNA activates dendritic cells via TLR9-dependent and -independent pathways. J Immunol 2005;174:6129-6136.

12. Yasuda K, Rutz M, Schlatter B, et al. CpG motif-independent activation of TLR9 upon endosomal translocation of 'natural' phosphodiester DNA. Eur J Immunol 2006;36:431-436.

13. Zhao $\mathrm{H}$, Hemmi $\mathrm{H}$, Akira $\mathrm{S}$, et al. Contribution of Toll-like receptor 9 signaling to the acute inflammatory response to nonviral vectors. Mol Ther 2004:9:241-248.

14. Stetson DB, Medzhitov R. Recognition of cytosolic DNA activates an IRF3-dependent innate immune response. Immunity 2006;24:93-103.

15. Krieg AM. CpG motifs in bacterial DNA and their immune effects. Annu Rev Immunol 2002;20:709-760.

16. Lorenz MG, Gerjets D, Wackernagel W. Release of transforming plasmid and chromosomal DNA from two cultured soil bacteria. Arch Microbio 1991;156:319-326.

17. Lorenz MG, Wackernagel W. Bacterial gene transfer by natural genetic transformation in the environment. Microbiol Rev 1994;58:563-602.

18. Allesen-Holm M, Barken $\mathrm{KB}$, Yang $\mathrm{L}$, et al. A characterization of DNA release in Pseudomonas aeruginosa cultures and biofilms. Mol Microbiol 2006;59:1114-1128.

19. Palchevskiy V, Finkel SE. Escherichia coli competence gene homologs are essential for competitive fitness and the use of DNA as a nutrient. J Bacteriol 2006;188:3902-3910.

20. Moscoso M, Claverys JP. Release of DNA into the medium by competent Streptococcus pneumoniae: kinetics, mechanism and stability of the liberated DNA. Mol Microbiol 2004;54:783-794.

21. Ottolenghi $E$, Hotchkiss RD. Appearance of genetic transforming activity in pneumococcal cultures. Science 1960;132:1257-1258.

22. Steinberger RE, Holden PA. Extracellular DNA in single- and multiplespecies unsaturated biofilms. Appl Environ Microbiol 2005;71: 5404-5410.

23. Steinmoen $\mathrm{H}$, Knutsen $\mathrm{E}$, Havarstein LS. Induction of natural competence in Streptococcus pneumoniae triggers lysis and DNA release from a subfraction of the cell population. Proc Natl Acad Sci USA 2002;99:7681-7686.

24. Whitchurch CB, Tolker-Nielsen T, Ragas PC, et al. Extracellular DNA required for bacterial biofilm formation. Science 2002;295:1487.

25. Petersen FC, Tao L, Scheie AA. DNA binding-uptake system: a link between cell-to-cell communication and biofilm formation. J Bacteriol 2005;187:4392-4400.

26. Soler-Rodriguez AM, Zhang $H$, Lichenstein HS, et al. Neutrophil activation by bacterial lipoprotein versus lipopolysaccharide: differential requirements for serum and CD14. J Immunol 2000;164:2674-2683.

27. Hailman E, Lichenstein HS, Wurfel MM, et al. Lipopolysaccharide (LPS)binding protein accelerates the binding of LPS to CD14. J Exp Med 1994;179:269-277.
28. Jaffe EA, Nachman RL, Becker CG, et al. Culture of human endothelial cells derived from umbilical veins. Identification by morphologic and immunologic criteria. J Clin Invest 1973;52:2745-2756.

29. Issekutz AC, Chuluyan HE, Lopes N. CD11/CD18-independent transendothelial migration of human polymorphonuclear leukocytes and monocytes: involvement of distinct and unique mechanisms. J Leukoc Biol 1995;57:553-561.

30. Krieg AM, Yi AK, Matson $\mathrm{S}$, et al. CpG motifs in bacterial DNA trigger direct B-cell activation. Nature 1995;374:546-549.

31. Sun $S$, Beard $C$, Jaenisch $R$, et al. Mitogenicity of DNA from different organisms for murine B cells. J Immunol 1997;159:3119-3125.

32. Middelhoven PJ, Van Buul JD, Hordijk PL, et al. Different proteolytic mechanisms involved in Fc gamma Rlllb shedding from human neutrophils. Clin Exp Immunol 2001;125:169-175.

33. Gaudry M, Bregerie O, Andrieu V, et al. Intracellular pool of vascular endothelial growth factor in human neutrophils. Blood 1997;90:4153-4161.

34. Borregaard N, Sorensen OE, Theilgaard-Monch K. Neutrophil granules: a library of innate immunity proteins. Trends Immunol 2007;28:340-345.

35. Bennett RM, Gabor GT, Merritt MM. DNA binding to human leukocytes. Evidence for a receptor-mediated association, internalization, and degradation of DNA. J Clin Invest 1985;76:2182-2190.

36. Loke SL, Stein $\mathrm{CA}$, Zhang $\mathrm{XH}$, et al. Characterization of oligonucleotide transport into living cells. Proc Natl Acad Sci USA 1989;86:3474-3478.

37. Yakubov LA, Deeva EA, Zarytova VF, et al. Mechanism of oligonucleotide uptake by cells: involvement of specific receptors? Proc Natl Acad Sci USA 1989;86:6454-6458.

38. Basner-Tschakarjan E, Mirmohammadsadegh A, Baer A, et al. Uptake and trafficking of DNA in keratinocytes: evidence for DNA-binding proteins. Gene Therapy 2004;11:765-774.

39. Benimetskaya L, Loike JD, Khaled Z, et al. Mac-1 (CD11b/CD18) is an oligodeoxynucleotide-binding protein. Nat Med 1997;3:414-420.

40. Emlen W, Rifai A, Magilavy D, et al. Hepatic binding of DNA is mediated by a receptor on nonparenchymal cells. Am J Pathol 1988;133:54-60.

41. Zhu FG, Reich CF, Pisetsky DS. The role of the macrophage scavenger receptor in immune stimulation by bacterial DNA and synthetic oligonucleotides. Immunology 2001;103:226-234.

42. McCoy SL, Kurtz SE, Hausman FA, et al. Activation of RAW264.7 macrophages by bacterial DNA and lipopolysaccharide increases cell surface DNA binding and internalization. J Biol Chem 2004;279: 17217-17223.

43. Kindrachuk J, Potter JE, Brownlie R, et al. Nucleic acids exert a sequence-independent cooperative effect on sequence-dependent activation of Toll-like receptor 9. J Biol Chem 2007;282:13944-13953.

44. Rutz M, Metzger J, Gellert T, et al. Toll-like receptor 9 binds single-stranded $\mathrm{CpG}$-DNA in a sequence- and pH-dependent manner. Eur J Immunol 2004;34:2541-2550.

45. Latz E, Verma A, Visintin A, et al. Ligand-induced conformational changes allosterically activate Toll-like receptor 9 . Nat Immunol 2007;8:772-779.

46. Brinkmann V, Zychlinsky A. Beneficial suicide: why neutrophils die to make NETs. Nat Rev Microbiol 2007;5:577-582.

47. Brinkmann V, Reichard U, Goosmann C, et al. Neutrophil extracellular traps kill bacteria. Science 2004;303:1532-1535.

48. Boxer LA, Haak RA, Yang HH, et al. Membrane-bound lactoferrin alters the surface properties of polymorphonuclear leukocytes. J Clin Invest 1982;70:1049-1057.

49. Bennett RM, Davis J. Lactoferrin interacts with deoxyribonucleic acid: a preferential reactivity with double-stranded DNA and dissociation of DNA-anti-DNA complexes. J Lab Clin Med 1982;99:127-138.

50. Romanowski G, Lorenz MG, Wackernagel W. Adsorption of plasmid DNA to mineral surfaces and protection against DNase I. Appl Environ Microbiol 1991;57:1057-1061.

51. Romanowski G, Lorenz MG, Sayler G, et al. Persistence of free plasmid DNA in soil monitored by various methods, including a transformation assay. Appl Environ Microbiol 1992;58:3012-3019.

52. Romanowski G, Lorenz MG, Wackernagel W. Plasmid DNA in a groundwater aquifer microcosm-adsorption, DNAase resistance and natural genetic transformation of Bacillus subtilis. Mol Ecol 1993;2: 171-181.

53. Matsukawa M, Greenberg EP. Putative exopolysaccharide synthesis genes influence Pseudomonas aeruginosa biofilm development. J Bacteriol 2004;186:4449-4456. 